\title{
POSSIBILITY OF REVERTER AND POWERS OF TERMINATION-FRATERNAL OR IDENTICAL TWINS?
}

\begin{abstract}
Artison DUNHAs**
G ENERATIONS OF LAW STUDENTS have been told by their teachers and the text writers that when A, owning a fee simple absolute, conveys Blackacre "to B and his heirs so long as no liquor is sold
\end{abstract} on the premises," A retains and B receives an interest which differs importantly from the interest of $A$ and $C$ in Whiteacre after a conveyance by $A$ "to $C$ and his heirs but on condition that if liquor is sold upon the premises C's estate shall be subject to a right of re-entry by $A$ and his heirs and C's estate shall become null and void." In Blackacre A is said to have a "possibility of reverter," but in Whiteacre he is said to have a "right of entry" or a "power of termination."' B is said to have a fee simple determinable or one subject to a special limitation while $C$ has a fee simple subject to a condition subsequent. ${ }^{3}$ The important difference said to arise from these labels is that B's estate ends "automatically" on the happening of the event (sale of liquor), while C's estate continues after the happening of the same event until A exercises the power of termination.

This concept of "expiration" on the one hand and "divestment" on the other does give us an interesting mental picture of the character of A, B and $C$ and of "the situation." As to Blackacre we can visualize B as a Casper Milquetoast who, on seeing a glass of beer sold on the premises, turns to a startled and "unexpecting" A, says, "Blackacre is yours, A" and then leaves the premises without claim or misgiving. With respect to

* Professor of Law, University of Chicago Law School.

1 A "possibility of reverter" is defined in the Restatement of Property $\$ 154(3)$ (1944) as "any reversionary interest which is subject to a condition precedent."

2 The Restatement of Property (hereafter referred to as Rest.) $\$ 155$ defines a "power of termination" as a future interest "created" in the transferor by the transfer of an estate subject to a condition subsequent.

8 Rest., $\$ 44$ describes a "fee simple determinable" as one which expires automatically upon the occurrence of a stated event. Section 45 describes a fee simple subject to a condition subsequent as one which provides that upon the occurrence of a stated event, the conveyor shall have a power to terminate the estate he created. Sections 23 and 24 of the Restatement describe a special limitation and a condition subsequent. 
Whiteacre we get an entirely different picture. Here we see an absentminded $\mathrm{C}$ (or perhaps a calculating $\mathrm{C}$ ) permitting a glass of beer to be sold and then becoming "fighting mad" when A, now in the costume of the cruel mortgagee of the old-fashioned melodrama, rushes forward a few hours after the beer has been sold with various official papers ordering a resisting $\mathrm{C}$ off the land.

When we convert Blackacre and Whiteacre into valuable urban property near the center of a prosperous city or profitable oil and gas land and when A becomes Mr. Albert Able and B becomes Mr. Brady Baker and C, Cadwallader Charles we get a different impression. Neither Baker nor Charles wants to give up the land on the happening of the event and both employ lawyers to resist Able's demand. We then see at once that whatever the label, Mr. Able must obtain the full fruits of his "right" by some kind of legal proceedings agaunst Baker and Charles and that the remedies available to him are substantially the same whether his interest be characterized as a possibility of reverter or a power of termination. Even if we assume that neither Baker nor Charles contests Able's right on the happening of the event, we begin to suspect that the title examiner employed by a purchaser from Able is going to insist that Able as vendor furnish as to both Blackacre and Whiteacre a quit claim deed from Baker and Charles releasing their "paper" rights. ${ }^{4}$

When it appears that in substantial matters such as A's power to sell after reclaiming the property, and A's remedies effectively to assert his right to reclaim, A must act in the same way with respect to Blackacre and Whiteacre, we may well ask what this alleged distinction really means. It is the purpose of this paper to consider wherein there is a real difference in legal consequences between a possibility of reverter and a power of termination. This task is difficult because we must inform our students that outside of the classroom "hypothetical" it is impossible to determine before litigation whether any given phrasing of a conveyance

"If any proof is needed of this probability, see the statutes imposing a "penalty" for failure to give such a release after the happening of the stated event. See, e.g., Kan. Gen. Stat. (1949) §55-201; Rev. Code of Montana, (1947) § 73-114. See also the numerous cases in which the purchaser has been subjected to a suit for specific performance where he has rejected the vendor's title on this ground or those in which the owner has sought a declaration of his title. Sherill v. Sherill, 211 Ala. 105, 99 So. 838 (1924) (condition subsequent, suit to cancel deeds of present estate); Thornton v. Middletown Educational Corp.,.21 Cal. App. 2d 707, 70 P. 2d 234 (1937) (condition subsequent, quiet title); Taylor v. McCowen, 154 Cal. 798, 99 Pac. 351 (1908) (special limitation, quiet title); Union Colony Co. v. Gallie, 104 Colo. 46, 88 P. 2d 120 (1938) (condition subsequent, quiet title); North v. Graham, 235 Ill. 178, 88 N.E. 267 (1908) (special limitation, quiet title); First Universal Soc. of N. Adams v. Boland, 155 Mass. 171, 29 N.E. 524 (1892) (special limitation, specific performance); Thypin v. Magner, 28 N.Y.S. 2d 262 (Sup. Ct. 2d Dept., 1941) (recission for unmarketable title, special limitation). 
will be interpreted as a special limitation or as a condition subsequent. ${ }^{5}$ Consequently we never can be certain of the reality of any theoretical difference between the two interests. A cautious judge who has determined upon what seems to him the just result can always attach the appropriate label to the phrasing at hand in order to avoid determining whether the opposite label would produce the same result or not. Thus if it is clear from the case law that an owner of a power of termination may "waive" a breach, absence of case law on the question whether an owner of a possibility of reverter may "waive" a breach may only mean that whenever the defense of waiver is allowed the judge has found language of condition in order to permit the defense to be asserted with certainty.

In this paper we will consider certain problems which may arise with respect to a defeasible estate in an effort to determine whether the label helps solve the problem. In all cases, of course, the conditioning event (e.g., sale of liquor) is assumed to be the same. For convenience of organization the problems will be subdivided into the following categories: 1) Possession, use and enjoyment of the subject matter; 2) Power to alienate voluntarily; 3) Power to determine devolution at death; 4) Termination or loss of right; and 5) Availability of remedies. This classification is not considered exhaustive but it is believed that it will give a fairly complete picture of the substantiality of differences between the two types of future interests. ${ }^{6}$

\footnotetext{
${ }^{5}$ See, e.g., Johnson v. Lane, 199 Ark. 740, 135 S.W. 2d 853 (1940) ("These lands are to revert" plus language of condition created determinable fee); Wolf v. Hallenbeck, 109 Colo. 70, 123 P. 2d 412 (1942) ("The title shall revert" held, condition subsequent language); United States v. 2,086 Acres of Land, 46 F. Supp. 411 (W.D. S.C. 1942) ("This deed to be null and void," said to be condition subsequent); Union Colony Co. v. Gallie, 104 Colo. 46, 88 P. 2d 120 (1939) (same); Union Missionary Baptist Church v. Fyke, 179 Okla. 102, 64 P. 2d 1203 (1937) (void, special limitation); Salt Lake City v. State, 101 Utah 543, 125 P. 2d 790 (1942) ("void" plus "revert," special limitation). See also McCall, Estates on Condition and on Special Limitation in North Carolina, 19 N.C. L. Rev. 334 (1941); O'Connell, Estates on Condition Subsequent and Estates on Special Limitation in Oregon, 18 Ore. L. Rev. 63 (1939); Williams, Restrictions on Use of Land, 27 Tex. L. Rev, 158 (1948).

- Many articles and texts mention one or more alleged differences: Ferrer, Determinable Fees and Fees Upon Condition Subsequent in California, 24 Cal. L. Rev. 512 (1936) (possibility of reverter passes by representation; power of determination by descent); McCall, op. cit. supra note 5 (power of termination can be released; possibility of reverter cannot); Niles, Conditional Limitations in Leases in New York, 11 N.Y.U.L.Q. 15 (1933) (lessor of lease on special limitation entitled to landlord's summary remedies; in lease on condition subsequent only entitled to ejectment).

Leach, Cases on Future Interests (2d ed., 1940) lists differences: 1) Where contingency is illegal or becomes impossible; 2) Liability for duties imposed on landowners; 3 ) Consequences of attempted alienation. 2 Powell on Real Property $\$ 191$ (1952) suggests differences as to rights of creditors of conveyor; statute of limitations; removal of fixtures.

Williams, Restrictions on Use of Land, 27 Tex. L. Rev. 158 (1948), lists eleven possible differences, the most important being rules such as waiver, estoppel and other forms of relief against forfeiture.
} 


\section{Possession, use and enjoyment.}

Since the present estates are defeasible, the future interest holders have certain protection against acts and omissions of the owner of the present interest. That protection is neither enlarged nor limited, however, by the label attached to the future interest so long as the limiting or terminating event has not occurred. Where the defeasible estate is a fee simple the control of the future interest on the conduct of the owner of the present estate is slight. Thus neither the holder of a power of termination nor the owner of a possibility of reverter can recover damages for waste, and they both can obtain injunctive relief against the holders of the present estates in limited situations only, ${ }^{7}$ and these situations do not turn on the kind of future interest the plaintiff has.

If, however, the terminating event has occurred, then there should be, in theory, a difference between the future interests as to the power over possession and enjoyment of the present estate. If the estate is subject to a condition subsequent, then the holder of a power of termination has, after the occurrence of the terminating event, the power to terminate the estate, but until that power is exercised the present estate continues. The acts constituting waste should now become more numerous since there is now a strong possibility that the estate will end. The owner of the power is now more clearly entitled to an injunction than before the happening of the event, but it is still doubtful whether he is entitled to damages for the act of waste, ${ }^{8}$ and it is clear that the happening of the event gives him no new right to rents and profits as the prior estate has not determined. He would, however, be entitled to rents and profits from the commencement of the ejectment action since that event, in most jurisdictions, determines the estate on condition subsequent. He has a right to possession.

If, on the other hand, the present estate was subject to a special limitation, that estate has terminated on the happening of the event and the law of waste no longer applies, but the applicable rules become those of the tortious use of the land of another. These rules would give the owner of the possibility of reverter not only damages for any conduct analogous to waste decreasing the value of the property but would give such owner an action for mesne profits from the time of termination of the present estate until the possibility of reverter holder has been given possession. Thus the owner of the present estate (condition subsequent) or formerly

${ }^{7}$ See Rest., $\$ 193$ (injunctive relief) and $\$ 194$ (recovery of damages).

${ }^{8}$ See the caveat to Rest., $\S 194$, where no position is taken as to recovery of damages from the owner of the formerly present estate after the interest of the owner of the future interest becomes a present interest. 
present estate (special limitation) has a duty enforceable by injunction not to reduce the present value of the premises. However, if he has after the happening of the stated event removed a building appurtenant to the land or otherwise damaged the land, the person formerly having a possibility of reverter is clearly entitled to damages, ${ }^{9}$ while the owner of the power of termination apparently is not entitled to damages for acts occurring before entry. ${ }^{10}$ As to injunctive relief the label attached to the defeasance clause appears not to be significant; as to the remedy of damages the case law appears to be silent as to the existence of the remedy in the hands of the owner of the power of termination. It is significant, however, that the litigation on the matter of removal of abandoned schools and churches seems to assume that damages are recoverable unless the building is a removable "trade fixture" or unless the conveyance gave a fee simple absolute to the conveyee."1

There does appear to be a theoretical difference between a possibility of reverter and a power of termination as to the time from which recovery of mesne profits is allowed. Case law does not develop the difference, if any, since such profits are recoverable only from the time the present estate is terminated. If, however, the estate on condition subsequent can be terminated by appropriate manifestation other than commencement of action, the difference is only formal. But in those states which, either by statute or common law, accord special treatment to occupying claimants who occupy in good faith ${ }^{12}$ there would seem to be no difference at all. This rule limits recovery of mesne profits or permits certain set-offs and credits where the defendant was in possession in good faith. The difficulty of determining in advance of litigation the correct label to be attached to the limiting clause should put practically all possessors claiming a defeasible present estate in the position of being claimants to possession in the good faith belief that possession is rightful until the formal claim is made or that there is no defeasance possible. ${ }^{13}$

'See Williams v. Kirby School District, 207 Ark. 458, 181 S.W. 2d 488 (1944); St. Louis S.W. Ry. v. Curtis, 113 Ark. 92, 167 S.W. 489 (1914); Nalley Land and Investment Co. v. Shaddix, 172 Ga. 171, 157 S.E. 291 (1931); Rustin v. Butler, 195 Ga. 389, 24 S.E. 2d 318 (1943).

${ }^{10} \mathrm{Cf}$. Rest., $\$ 194$.

"See dissent and majority opinion in, In Re Copp's Chapel Methodist Church, 120 Ohio St. 309, 166 N.E. 218 (1929).

${ }^{12}$ See, e.g., Tllinois occupying claimants' statute, Tll. Rev. Stat. (1951) c. $45, \S 53$, disallowing claim for profits "prior to receipt of actual notice of the adverse claim" if the evicted defendant can show a record title and that he is without notice of an adverse record title. See generally, Warvelle on Ejectment $\S 534$ (1905); Annotations, 104 A.L.R. 577 (1936), 137 A.L.R. 1078 (1942).

${ }^{13}$ Cf. Santmeyer v. Clemmancs, 147 Wash. 354, 266 Pac. 148 (1928). 
With respect to duties imposed on a person by reason of ownership of a present estate in land there should in theory be a difference between the two types of estates. Thus where real property taxes are a personal obligation of an owner, taxes assessed after occurrence of the stated event should be a personal obligation of the owner of the former possibility of reverter but not an obligation of the owner of a power of termination. ${ }^{14}$ Most rules of this type, however, impose duties on the possessor or persons in control of the land. Thus the duty to provide lateral support is on the actor, not the landowner, and the duty not to permit dangerous conditions on the premises is a duty of possessors of land and not of owners. Since by hypothesis neither future interest holder has possession this type of liability ought not to turn on whether the present estate was determinable or subject to a condition subsequent..$^{15}$

\section{Power to alienate voluntarily and involuntarily.}

While either type of defeasible present estate is freely alienable and reachable by creditors if the defeating event is not alienation, ${ }^{16}$ there is a possible difference in legal consequences if the defeating event is an attempted transfer. Assuming the restraint on alienation is valid, if the restraint is in the form of a special limitation, the present estate should terminate automatically on attempted alienation and the transfer would be ineffective to create an interest in the transferee. If the restraint on alienation is in the form of a condition subsequent, the attempted transfer should be effective to create an interest in the transferee, but one subject to defeasance. In most instances, however, a dispute between the conveyor and the successor of the conveyee would involve identical questions ${ }^{17}$ with those considered in a dispute between conveyor and conveyee or between third persons and conveyor or conveyee, so that the legal consequences of a rule which says the one has no power to create an interest in the transferee while the other does have the power will be the same

14 There are very few claims of this type possible. Conceivably there could be a covenant running with the land which imposes personal liability on the owner of the present estate, but it would have to be one which was prior in time to the creation of the defeasible estate and survived the defeasance of the former present estate.

${ }^{15}$ In Cassidy v. Welsh, 319 Mass. 615, 67 N.E. 2d 226 (1946), it was argued that after nonpayment of rent under a lease determinable on that event, the lessor had legal control of the premises sufficient to impose tort liability on the lessor for a dangerous condition on the premises. The Court found the defeasance clause to be a condition so it was unnecessary to decide the question argued by plaintiff. It would not seem that the "control" attributable to the rights accruing on automatic termination of the prior estate would be sufficient to impose liability on the former possibility of reverter. See Restatement of Torts $\$ \$ 329-87$.

${ }^{16}$ See Rest., $\$ \$ 0$ and 52.

${ }^{17}$ E.g., disputes concerning waste, mesne profits; waiver and relief against forfeiture. 
legal consequences as under the rule that in one the estate ends automatically and in the other it is subject to defeasance.

With respect to the future interests, the question of alienability presents one of the most important differences noted by the text writers. The Restatement of Property declares that the owner of a possibility of reverter has the power to transfer his interest, ${ }^{18}$ but that the owner of a power of termination does not have such power except in a limited number of situations. ${ }^{19}$ Interestingly enough those text writers who assert that there are important differences between the two types of future interests which need not be disturbed are usually the writers most disturbed about this particular difference and the writers who find this difference unnecessary and indefensible. ${ }^{20}$ Since the liability of an interest to claims of judgment creditors is made by the Restatement to turn on the power of voluntary alienation, ${ }^{21}$ the difference between the two types of future interests extends also to liability to claims of creditors.

How real is this asserted difference? That historically this difference existed there appears to be no doubt. ${ }^{22}$ That it now exists depends on whether two hundred year old history is to be regarded as more significant than recent history. ${ }^{23}$ Recent history would indicate that in almost every instance of legislation on the alienability of these future interests, the objective of the statute has been to treat the future interests in the same way - either make both alienable or both inalienable. ${ }^{24} \mathrm{~A}$ description of the present situation in the United States would show that at least twentyfour jurisdictions have identical rules as to both types of future interests; ${ }^{25}$

${ }^{18}$ Rest., $\$ 159$. ${ }^{19}$ Rest., $\$ \S 160$ and 161.

${ }^{20}$ See, e.g., 2 Powell on Real Property $\$ \$ 281$ and 282 (1952) and articles therein cited.

${ }^{21}$ Rest., $\$ 186$. 222 Powell on Real Property $\S \S 281$ and 282 (1952).

${ }^{23}$ The restaters frequently read the older case history as of more significance than recent case and legislative history. Thus when faced with the question whether words of inheritance were necessary to create a fee simple, the restaters $(\$ 27)$ answered yes, ignoring, as part of the common law, the statutory changes and changes by decision which had occurred since the time of Coke. For an imaginative use of statutes to change the common law, see Lehman J. in Agar v. Orda, 264 N.Y. 248, 190 N.E. 479 (1934) (policy of Uniform Sales Act applied to determine "common law" rules for sales of choses in action). See also Commercial Nat'l Bank of New Orleans v. Canal-Louisiana Bank \& Trust Co., 239 U.S. 520 (1916).

21 Ill. Rev. Stat. (1951) c. 30, $\$$ 37b-37h makes both types of future interests inalienable. The following statutes either expressly or by interpretation have been held to make the power of termination alienable: Cal. Civ. Code. (1949) §1046; Conn. Gen. Stat. (1949) § 7118; Idaho Code Ann. (1948) § 55-502; Kan. Gen. Stat. (1949) §\$67-202, 67-308, 77-201; Ky. Stat. (Baldwin, 1943) \& 381.040; Mich. Comp. Laws (1948) §554.111; Minn. Stat. Ann. (1949) $\$ 500.16$; R.I. Gen. Laws (1938) c. 433, § 10; Tex. Civ. Stat. (Vernon, 1949) Art. 1296; Va. Code (1950) §55-56; W.Va. Code (1949) §3529.

${ }^{25}$ In addition to the 12 states cited in note 24 supra, the following states have decisions either making both inalienable, both alienable or decisions making power of termination alien- 
that only a few have clear decisions holding one type alienable and the other type inalienable; ${ }^{26}$ and that most of the remaining jurisdictions are silent on one or both types of interest. The most recent series of cases on the question of alienability led the Oklahoma Supreme Court to conclude that there is no difference between a possibility of reverter and a power of termination on any point. ${ }^{27}$

\section{Power to determine devolution at death.}

Both types of present interests and both types of future interests are inheritable and devisable. ${ }^{28}$ While at one time there appeared to be a difference between a possibility of reverter and a power of termination as to whether the heir who took such an interest took "by representation,"29 this distinction seems to have disappeared from the law and powers of termination and possibilities of reverter are now treated as are any other future interest.

able. With respect to the latter group and to the states having statutes applicable only to powers of termination it is fair to assume that when faced with the possibility of reverter situation that interest will also be held to be alienable.

Arkansas: Moore v. Sharpe, 91 Ark. 407, 121 S.W. 341 (1909) (power of termination alienable); Colorado: Denver \& S.F. Ry. Co. v. School Dist., 14 Colo. 327, 23 Pac. 978 (1890) (both inalienable); Florida: Richardson v. Holman, 160 Fla. 65, 33 So. 2d 641 (1948) (dictum that power of termination is alienable and holding that possibility of reverter is alienable); Georgia: Williams v. Thomas County, 208 Ga. 103, 65 S.E. 2d 412 (1951) (dicta as to alienability of both types); Iowa: Reichard v. Chicago B. \& Q. R. Co. 231 Ta. 563, 1 N.W. 2d 720 (1942) (dicta that both are alienable); North Carolina: Blue v. Wilmington, 186 N.C. 321, 119 S.E. 741 (1923) (both inalienable); Oklahoma: Kassner v. Alexander Drug Co., 194 Okla. 36,147 P. 2d 979 (1944) (both alienable); Oregon: Magness v. Kerr, 121 Ore. 373, 254 Pac. 1012 (1927) (both alienable); Pennsylvania: McKissick v. Pickle, $16 \mathrm{~Pa} .140$ (1851) (power of termination alienable); Slegel v. Lauer, 148 Pa. 236, 23 Atl. 996 (1912) (possibility of reverter alienable); Tennessee: Yarbrough v. Yarbrough, 151 Tenn. 221, 269 S.W. 36 (1924) (possibility of reverter).

${ }^{26}$ See, e.g., Indiana: Kessler v. City of Indianapolis, 199 Ind. 420, 157 N.E. 547 (1927) (possibility of reverter alienable); Fall Creek School Township v. Shuman, 55 Ind. App. 232, 103 N.E. 677 (1913) (power of termination inalienable); but see McAdams v. Bailey, 169 Ind. 518, 82 N.E. 1057 (1907); Massachusetts: Rice v. Boston \& Worcester R. Co., 12 Allen (Mass.) 141 (1866) (power of termination inalienable); Dyer v. Siano, 298 Mass. 537, 11 N.E. $2 \mathrm{~d} 451$ (1937) (possibility of reverter assumed to be alienable). There are very few other jurisdictions where the difference is clear.

See also the states which make the possibility of reverter inalienable but are silent as to the power of termination. Such states are also likely to produce identical rules as to alienability. See Delaware: Addy v. Short, 81 A. 2d 300 (Del. Super., 1951) (dictum as to possibility of reverter); Cookman v. Sillman, 22 Del. Ch. 303, 2 A. 2d 166 (1938) (dictum same).

${ }^{27}$ Kassner v. Alexander Drug Co., 194 Okla. 36, 147 P. 2d 979 (1944); Fuhr v. Oklahoma City, 194 Okla. 482, 153 P. $2 d 115$ (1944). See Browder, Defeasible Fee Estates in Oklahoma, 4 Okla. L. Rev. 141 (1951).

28 Rest., $\S \S 164$ and 165.

${ }^{29}$ Rest., § 164, Comment c. Compare Upington v. Corrigan, 151 N.Y. 143, 45 N.E. 359 (1896), with North v. Graham, 235 Ill. 178, 85 N.E. 267 (1908). 


\section{Termination or ineffectiveness of future interest.}

The attempt to make the present estate defeasible may be thwarted by various rules. Thus the limitation or condition may be void as against public policy or as a violation of the rule against perpetuities; the defeasibility may lapse by reason of changed circumstances, impossibility of occurrence, or by reason of some action or nonaction of the owner of the future interest producing a waiver or an estoppel, or by reason of lapse of time. In general none of these rules depend for their applicability on a determination of whether the future interest was a possibility of reverter or a power of termination.

Ineffectiveness of a future interest in its inception. The limitation or condition may be found to be illegal because it is anti-social, e.g., in many circumstances estates are limited or conditioned on marriage or failure to marry. If the limitation or condition is illegal it becomes necessary either to construe the creating instrument to try to determine what the grantor would have intended had he been confronted with the possibility of illegality or to determine without regard to intention what should happen to the present estate. While it is possible to construe the whole conveyance as ineffective, the usual construction is to make the present estate absolute. ${ }^{30}$ In no event does the choice of these two construction possibilities turn on the kind of defeasible estate which was attempted, and in no case does the validity of the limiting event turn on whether it is stated in language of condition or of limitation.

In the United States, unlike England, neither a possibility of reverter nor a power of termination is subject to the rule against perpetuities. If, however, after the defeasible estate the grantor attempts to make a gift over on the happening of the event to some person other than the conveyor, the rule against perpetuities is applicable. If the rule against perpetuities voids the gift over, a problem similar to that in the preceding paragraph is presented and it is necessary to determine whether the present estate also fails, becomes indefeasible or remains defeasible subject to a possibility of reverter or power of termination in the grantor. Like the preceding situation the problem is to determine the intent of the grantor, and like the preceding situation there is a construction preference for making the present estate indefeasible. ${ }^{31}$ According to the Restatement of Property, Section 229, there must be an affirmative manifestation of an intent that the happening of the event upon which the executory interest

${ }^{80}$ See Rest., $\$ 228$, Comment d.

31 Rest., $\$ 229$. 
was limited should terminate the prior interest even though the executory interest is ineffective before the construction preference is overcome. The question is whether language of one of the two types of defeasance clauses is such an affirmative manifestation without more, because where the purpose of the conveyor is otherwise determinable there can be no difference between language of condition and language of limitation. The Restatement of Property, basing its rule on four early cases, finds that language of limitation is such an affirmative manifestation of an intent to make the estate defeasible regardless of what happens to the executory interest while language of condition is not such a manifestation. ${ }^{32}$ Here then is a rule which applies differently in limitation and condition cases, if it is followed. The new Pennsylvania Estates Act of 1947 makes the present estate indefeasible in all cases where the rule against perpetuities voids the gift over. ${ }^{33}$ Since the normal case involving this problem of construction will also involve a problem of determining whether the language is that of condition or limitation, the construction preference for indefeasibility should produce a characterization of the interest as one of condition rather than one of limitation. In other words, except in the most expertly drafted instruments the dispute will be decided not on the validity of the Restatement position but on the question of characterization of the defeasance clause.

Termination by reason of changed circumstances. This doctrine is that commonly applied to equitable servitudes and renders them unenforceable when the reason for the restriction has passed. The applicability of this doctrine to defeasible estates is too new to determine whether its applicability will turn on the characterization of the defeasance clause. The cases applying it have been conditions; the theory of estates should make the doctrine inapplicable to either type of future interest; the policy of the changed circumstances doctrine should make it applicable to both types. ${ }^{34}$

Termination by estoppel, waiver or relief against forfeilure. Where an event has occurred which the holder of the future interest claims to have caused a termination or defeasance of the present estate, the owner of this latter estate may claim (1) the terminating event has not occurred. Thus

\footnotetext{
${ }^{32}$ Rest., $\$ 229$, Comment e, and Monograph on Ineffectiveness of an Ultimate Executory Interest in Appendix to Volume 2.

${ }^{33}$ Penn. P. L. 100 \$ (1947), Pa. Stat. Ann. § 301.5 (1950).

st See Goldstein, Rights of Entry and Possibilities of Reverter as Devices to Restrict the Use of Land, 54 Harv. L. Rev. 248 (1940). See also Minn. Stat. (1949) $\$ 500.20$ making the doctrine of changed circumstances applicable, according to the title, to "defeasible estates" but according to text when any "conditions" are annexed to a grant. See page 230 infra for problem of construction.
} 
he may argue that he has substantially complied with the terms of the conveyance and that a proper construction requires a finding that only on failure of substantial compliance should there be a defeasance. ${ }^{35}$ (2) The holder of the future interest has, by his conduct subsequent to the happening of the event, prevented himself from now asserting termination or power to terminate by reason of a "waiver" or an "estoppel." (3) The right or power cannot be asserted because equity will not enforce a forfeiture.

The first claim is a defense equally applicable to an estate on limitation and an estate on condition. The defense of estoppel is also a doctrine equally applicable to both types of future interest since estoppel may operate to prevent a person from asserting his ownership as well as to prevent him from asserting a power. ${ }^{36}$ There may be a difference in applicability however. The estate on condition gives the future interest holder an election as to termination and once he elects not to terminate, the election is irrevocable. Normally an election does not require reliance by the person asserting that an election has occurred, whereas an estoppel does. It may be that conduct of the owner of a power of termination will be evidence of an election not to terminate before similar conduct produces an estoppel against the owner of the former possibility of reverter because of the element of reliance. If, however, there is justifiable reliance by the holder of the present estate such as arises where the future interest owner stands by after the happening of the terminating event and permits the present estate owner to make substantial improvements, estoppel would operate in either case and without regard to the form of the defeasance clause. The difference between the two estates, if any, arises because the owner of the estate on condition has two arrows to his bow-a defense of an election not to terminate and a defense of estoppel-while the owner of the estate on limitation can in theory assert only an estoppel.

Technically the doctrine of "waiver" is not applicable to either type of defeasible estate. In the condition type it is more proper to say that the owner of the power of termination has "elected" not to terminate than to say he "waived" his power. In the limitation type it is difficult to conceive of a "waiver" of a "present" estate, which is what waiver would amount to after happening of the limiting event. Conduct of the holder of the pos-

\footnotetext{
35 While the doctrine of "substantial performance" can be said to be a matter of construction, its use to avoid forfeitures warrants noting the rule in this paper. As illustrations of its use in defeasible estates, see Davis v. Skipper, 125 Tex. 364, 85 S.W. 2d 318 (1935) (special limitation); Bernard v. Bowen, 214 N.C. 121, 198 S.E. 584 (1938) (special limitation).
}

${ }^{36}$ Ewart, Estoppel by Misrepresentation 251-95 (1900). 
sibility of reverter may "imply" a reconveyance or an agreement to reconvey, and probably the conduct which courts speak of as a "waiver" is this kind of conduct. Thus the English equity courts often ordered the landlord to execute a new lease where the landlord, after the estate for years on limitation had terminated, accepted new rent or otherwise treated the former tenant as if he were still a tenant. ${ }^{37}$ They found this agreement to continue the tenancy on substantially the same facts, where in an estate for years on condition they said the landlord had "elected" not to terminate. Less accurate courts might find a "waiver" in both cases. ${ }^{38}$

This implied agreement is more difficult to find when the estate on limitation is a fee simple however because of the difficulty of determining what the duration term of the implied agreement is and because of the statute of frauds. It is probable that proof sufficient to establish an implied agreement to reconvey an absolute estate is substantially the proof required for an estoppel. This would mean in comparing the two estates that an election not to terminate is more easily found than is an estoppel or implied agreement to continue and that the latter two concepts and not that of election are applicable to estates on limitation.

With respect to relief against forfeiture, it is sometimes said that equity will only act to prevent a forfeiture and that when the prior estate has terminated or been terminated before the aid of equity is asked then equity has no forfeiture to relieve against. ${ }^{39}$ If this were the rule, then, the estate on limitation, having terminated, could not invoke this equitable doctrine. But this asserted limitation on the power of the equity court is nonsense, for equity can set aside a forfeiture or allow the prior owner to continue as though a forfeiture had not occurred just as well as it can prevent a forfeiture from taking place. ${ }^{40} \mathrm{It}$ is sometimes said, however, that equity will require a stronger case to set aside a forfeiture than to prevent one from occurring.

The more difficult conceptual thinking to overcome, however, is the idea that there is no forfeiture involved in the estate on limitation. The estate has not been forfeited; it has only ended naturally as the parties agreed. Of course both types of estates only end as the parties agree, and if court interference with an agreement is possible in one case, it is also

${ }^{37}$ See, e.g., Hare v. EImo, [1893] 1 Q.B. 607; Ewart, Waiver Redistributed 104 (1917).

${ }^{38}$ See Ewart, ibid., at 151-67; on waiver of right of entry, see 1 Simes, Future Interests $\S 170$ (1936).

${ }^{39}$ See, e.g., Maginnis v. Knickerbocker Ice Co., 112 Wis. 385, 88 N.W. 300 (1901).

${ }^{40}$ See Annotation, 69 L.R.A. 833 (1901). 
possible in the other. Nevertheless courts have had difficulty with this normal ending idea in contrast to the forfeiture. Thus courts, which have no difficulty in preventing operation of a condition where the person asserting the happening of the conditioning event caused its occurrence, experience difficulty where the person asserting benefit of the limitation caused the happening of the event. Thus courts have had difficulty in giving relief to the heirs of a deceased owner whose estate was terminable on death even though the person claiming the succeeding estate caused the death of the life tenant. ${ }^{41}$ In one case in an estate on special limitation, where the happening of the terminating event was caused by the holder of the possibility of reverter, the court said that the latter was "estopped" from asserting that the prior estate had terminated. ${ }^{42}$

There is enough case law applying, or indicating a willingness to apply, the doctrines of estoppel, waiver and relief from forfeiture to estates on limitation after alleged termination ${ }^{43}$ and enough cases refusing to apply the same doctrines to estates on condition ${ }^{44}$ to suggest that here as elsewhere the applicability of the doctrines depends on the problem before the court and not on the characterizations of interests. Thus when the parties have clearly indicated that a forfeiture was intended, and a forfeiture is the only way to do justice to the parties, equity will permit a forfeiture. This suggests that the availability of these defenses does not turn on the kind of defeasance clause but on its purpose.

Where the purpose of the defeasance clause is to terminate or permit termination of the estate after the purpose for which the conveyance was made has ceased to have meaning, then the courts have refused to apply "waiver" or "estoppel" or "relief against forfeiture" to either type of future interest where the future interest holder has merely been slow in asserting his rights or powers. Thus where land was conveyed for the purpose of a public building and the land is no longer used as such, mere inac-

${ }^{1}$ See, e.g., Welsh v. James, 408 Ill. 18, 95 N.E. 2d 872 (1950); Wade, Acquisition of Property by Wilfully Killing Another: A Statutory Solution, 49 Harv. L. Rev. 715 (1936).

12 Humble Oil \& Refining Co. v. Harrison, 146 Tex. 216, 205 S.W. 2d 355 (1947); Kouns v. Southwest Oil Co., 203 Ark. 469, 158 S.W. 2d 37 (1942) (lessor's negligence caused termination); Mitchell v. Cheney Slough Irrigation Co., 57 Cal. App. 2d 139 (1943) (default for twelve or more years).

43 See Woollard v. Schaffer Stores, 272 N.Y. 304, 5 N.E. 2 d 830 (1936), noted in 15 N.Y.U. L.Q. 286 (1938); Browning v. Weaver, 158 Kan. 255, 146 P. 2 d 390 (1944); Bloom v. Rugh, 98 Kan. 589, 160 Pac. 1135 (1916); Mitchell v. Simms, 63 S.W. 2d 371 (Tex. Comm. App., 1933); Transcontinental Oil Co. v. Spencer, 6 F. 2d 866 (C.A. 5th, 1925). See Equitable Relief from Termination for Failure To Make Delay Rental Payment on Time, 22 Miss. L.J. 118 (1950).

44 See cases cited in note 45 infra, and cases cited in The Application of the Rule against Forfeitures in the Termination of Oil and Gas Leases, 29 Calif. L. Rev. 386 (1941). 
tion for a period short of the period of the applicable statute of limitations is not enough to cause a cessation of the rights of either a possibility of reverter or a power of termination. ${ }^{45}$ The early writers tended to look upon this purpose as the proper purpose for a special limitation, and it may be that this is the reason that they did not consider the applicability of the above mentioned defenses to a special limitation.

Where however the purpose of the defeasance clause is to penalize for noncompliance with a required course of conduct, then unless the parties and circumstances clearly indicate that time is of the essence in securing compliance with the specified course of conduct, some kind of relief against forfeiture is given if the circumstances warrant. It was this purpose which the early writers thought to be the usual purpose of a condition subsequent, and it may be that it is this reason which made the equitable relief against forfeiture doctrine so well developed where language of condition was used.

Probably because of the development of this doctrine with respect to conditions, draftsmen turned to language of limitation when they meant that time was of the essence and that compliance was clearly to be required. If there is a clearly intended time-is-of-the-essence clause, equity is less likely, if at all, to relieve against a forfeiture. If we look at language of limitation in this setting it appears to be, when it is used to compel conduct, a form of clause telling the equity court that the parties really mean forfeiture.

That it is the purpose of the defeasance rather than the form which determines the availability of the above mentioned defenses is aptly illustrated by comparing the California and Texas oil and gas leases. In Texas the limitation language is used to impress upon the court that time is of the essence in performance of the oil and gas lease, and in general the courts have responded by refusing to relieve against forfeiture except in rare cases where language of limitation is used. ${ }^{46}$ In California, on the other hand, substantially the same result is reached in leases where language of condition is used. ${ }^{47}$ The essence of the situation in both states is that oil and gas law needs "sudden death" provisions for noncompliance

${ }^{45}$ Trustees of Union College v. City of New York, 173 N.Y. 38, 65 N.E. 853 (1903) (power of termination, more than twenty years of nonexercise of power; no waiver, election or estoppel); City of New York v. Coney Island Fire Department, 170 Misc. 787, 10 N.Y.S. 2d 164 (1939) (same, forty years).

${ }^{46}$ See case comments, 26 Tex. L. Rev. 826 (1948), 27 Tex. L. Rev. 561 (1949), and Williams, Restrictions on Use of Land: Conditions Subsequent and Determinable Fees, 27 Tex. L. Rev. 158 (1948).

${ }^{47}$ See Note, op. cit. supra note 44. 
with lease provisions, but in both states equity does intervene where the circumstances are exceptionally strong for relief to the lessee. The more the language of limitation is used to penalize for nonperformance of required conduct, the more the courts are likely to intervene to prevent a forfeiture except where the situation requires that kind of penalty. Less difficulty in developing precedent will occur if the problem is approached directly rather than approaching it as a problem of determining whether one form of defeasance language was used rather than another.

Termination by lapse of time. Nonaction by the owner of the future interest after occurrence of the conditioning or limiting event may result in loss of right or power by reason of a statute of limitations or rule of laches. It seems clear that the statute of limitations begins to run against the holder of a possibility of reverter from the occurrence of the limiting event $t^{48}$ and that possession of the holder of the late present estate would be sufficiently notorious and hostile to give him title by adverse possession. ${ }^{49}$ Since the estate subject to a condition subsequent is not terminated until re-entry, possession of the present estate owner should in theory never be hostile until after exercise of right of entry. Thus some courts hold that the statute of limitations does not begin to run until entry. ${ }^{50} \mathrm{By}$ statute and decision the prevailing position today seems to be that the statute begins to run from the date the right to enter first accrues, ${ }^{51}$ and these statutes and decisions would seem to make the two types of future interest subject to the same liability as far as adverse possession is concerned.

In addition to the traditional type of statute of limitations, some states have statutes designed to cut off stale claims for the purpose of making

48 See Concepcion de Storke v. Penn. Mutual Life Ins. Co., 390 Ill. 619 (1945); School Dist. Twp. v. Hausen, 186 Ia. 1314, 173 N.W. 873 (1919).

${ }^{49}$ But see School Dist. Twp. v. Hausen, 186 Ia. 1314, 173 N.W. 873 (1919); cf. Moore v. Hoffman, 327 Mo. 852, 39 S.W. 2d 339, 75 A.L.R. 147 (1931) (possession of widow after expiration of quarantine where right to dower has expired).

${ }^{50}$ City of New York v. Coney Island Fire Dept., 170 Misc. 787, 10 N.Y.S. 2d 164 (1939), aff'd, 259 A.S. 286, 18 N.Y.S. 2d 923 (1939) (breach in 1895; action of ejectment begun in 1935). See 1 Simes, Future Interests $\$ 170$ (1936).

51 Hoke v. Central Twp. Farmers Club, 194 Mo. 576, 91 S.W. 394 (1906) (statute); Sanford v. Sims, 192 Va. 614, 66 S.E. 2 d 495 (1951); Note, 38 Va. L. Rev. 266 (1951) (common law decision); Ark. Stat. Ann. (1947) § 37-104; Minn. Stat. (1949) §500.20; Cal. Code Civ. Proc. (1950) §320.

Unless such statutes are construed to give an indefeasible title to the holder of the present estate, he may have difficulty under some types if the right of entry is exercised through selfhelp and not legal process. See, e.g., Colo. Stat. Ann. (Supp., 1951) c. 40, \$154, providing that "actions to recover" possession for any violation of any "restriction" must be brought within one year. 
the title to land more marketable. Most of these refer to "conditions" or "restrictions" and few if any use the term "limitations." Since the reason for cutting off stale claims is applicable to limitations as well as conditions, it would seem that the legislature was not using the word "condition" in its technical sense. Thus "easements" have been held to be "conditions or restrictions," 53 and conditions subsequent have been held to be "restrictions."

Another type of statute also seems applicable to terminate both types of interest if it terminates any. This is the so-called "marketable title" statute. These statutes frequently except "conditions." If this phrasing is meant to be technical language, an anomalous result follows: the statutes cut off possibilities of reverter and not powers of termination. $.^{56} \mathrm{Cer}-$ tainly the policy of these statutes does not permit a distinction between possibilities of reverter and powers of termination. Either both should be excepted from the statute or both included. ${ }^{57}$

\section{Availability of remedies.}

Recovery of possession. At early common law, "right of entry" meant what it said, and in order to terminate the estate on condition subsequent, the owner of the right of entry had to enter and then bring his action for possession. ${ }^{58}$ There was then a difference between a special limitation and a condition subsequent because the owner of a possibility of reverter could commence his action for recovery of possession without the formality of entry. Today the necessity of entry is gone in all American jurisdictions.

${ }^{52}$ Colo. Stat. Ann. (Supp., 1951) c. $40, \$ 154$ (actions to recover for violations of "restrictions"); Minn. Stat. (1949) $\$ 500.20$ ("covenants, conditions or restrictions" cease after 30 years); Mass. Ann. Laws (Supp., 1951) c. 184, $\$ 23$ ("conditions, restrictions, reservations, stipulations, or agreements"); nll. Rev. Stat. (1951) c. $30, \$ \$ 37 \mathrm{~b}-37 \mathrm{~h}$, and Ind. Stat. Ann. (1951) § 2-628 refer to "possibility of reverter" and "limitations."

${ }^{53}$ Crocker v. Cotting, 173 Mass. 68, 53 N.E. 158 (1899).

54 Wolf v. Hallenbeck, 109 Colo. 70, 123 P. 2d 412 (1942).

55 Minn. Stat. (1949) $\S 541.023$ ("conditions subsequent or restrictions"); Neb. Rev. Stat. (1950) $\$ 76.2$ ("conditions subsequent"); N.D.L. (1951) c. $280, \S 11$ (same); S.D.L. (1947) c. $233, \S 10$ (same).

${ }^{56}$ Statutes such as the Michigan statute which do not refer to either type of defeasible estate may not apply to either type except in the probably rare situation where conveyances during the prescribed period (usually 40 and more years) refers either to an earlier deed with the defeasance in it or to the defeasance itself. Where the conveyances during the statutory period continue to refer to the original conveyance establishing the defeasance, and the statutes seem to operate only to give a marketable title in a defeasible estate. See Aigler, Clearance of Land Titles-A Statutory Step, 44 Mich. L. Rev. 45, 53 (1945), suggesting identical treatment.

${ }^{57}$ For general discussion of these statutes see Aigler, ibid.

s8 1 Simes on Future Interests $\$ 167$ (1936). 
The only survival is the requirement in some jurisdictions of election to terminate (usually by notice) before commencement of action. ${ }^{59}$ The term "power of termination" suggests that sometimes something short of entry or commencement of suit may also serve to terminate the estate on condition. ${ }^{60}$ The more something short of suit or entry is recognized the more the power of termination approaches the possibility of reverter. It is only where notice before suit is a requirement that any important difference can be said to exist.

Some special remedies for recovery of possession may perpetuate the difference. Thus summary dispossess proceedings or forceable detainer proceedings may by statute be limited to removal of tenants "holding over"61 after the expiration of a term and not be specifically available as a means of terminating an estate for years on breach of condition. The New York courts, for example, reasoned that an estate on condition did not terminate until after entry or suit commenced, and in such a case the summary proceedings were not available to terminate because the tenant was not a holdover tenant. ${ }^{62} \mathrm{New}$ York leases accordingly attempt to make of leaseholds estates on limitation which end automatically on the occurrence of stated events (usually breach plus notice plus expiration of a period of time after notice). Thus after the stated events have occurred, the landlord can proceed against the tenant as a holdover tenant. Most other jurisdictions do not make this distinction; perhaps they permit an estate on condition to be terminated by something (e.g., notice) short of entry or commencement of action.

Quiet title proceedings. Where a proceeding to quiet title can be brought only by claimants in possession, neither the owner of a possibility of reverter nor of a power of termination can utilize this type of proceeding. until he recovers possession. ${ }^{63}$ In other jurisdictions both should be able to utilize such proceedings, unless the remedy is limited in the case of powers of termination by a rule which requires a previous declaration of forfeiture $^{64}$ or a rule which says that equity will not aid in the declaration of

${ }^{50} \mathrm{Tbid}$. The majority of jurisdictions seem to reject this requirement. See 4 Thompson on Real Property $\$ 2136$ (1940).

"0 Special Note, Rest., $\$ 24$ states that "any appropriate manifestation" of an "intent thereby to terminate" is sufficient.

${ }^{61}$ See, e.g., N.Y.C.P.A. (1931) Art. 83.

62 Burnee Corp. v. Uneeda Pure Orange Drink Co., 132 Misc. 435, 230 N.Y. Supp. 239 (First Dep't., 1928). See Niles, Conditional Limitations in Leases in New York, 11 N.Y.U.L.Q. Rev. 15 (1934).

63 See generally, 4 Pomeroy, Eq. Jur. $\$ 1395$ et. seq. (5th ed., 1941).

64 See text and notes at notes 59 and 60 supra. 
a forfeiture. ${ }^{65}$ A substantial number of jurisdictions permit the holder of a right of entry to quiet title before entry ${ }^{66}$ Wherever this is the rule there is no difference between the types of future interests here considered. It would seem, however, that sufficient strength remains to the doctrine that equity will not enforce a forfeiture to say that the owner of a power of termination cannot assert his power by a quiet title proceeding. Can the owner of a possibility of reverter? The analysis suggested earlier ${ }^{67}$ would seem to answer yes. The theory of automatic ending seems to have some force here.

Partition. When the possibility of reverter or power of termination is owned by two or more persons as concurrent owners, can one of the concurrent owners resort to partition and by joining the owner of the present estate obtain a determination of rights in the property? Where possession is a prerequisite to partition neither type of future interest can maintain partition; where by statute only the owner of an unconditional and indefeasible future interest can compel partition, neither type of future interest can qualify before the happening of the limiting or conditioning event.

Under two types of statute there may be a difference between the two types of estates: (1) where the statute permits any "present interest" to compel partition; and (2) where the statute permits indefeasibly vested future interests to compel partition and the conditioning event has happened. ${ }^{68}$ The Restatement of Property seems to treat both types of interests as "present interests" after the happening of the limiting event.69 Illinois has decided that the holder of a possibility of reverter can compel partition where he alleges the previous happening of the terminating event. ${ }^{70}$ Perhaps it is because of the applicability of the equitable princi-

${ }^{65}$ See, e.g., Newton v. Village of Glen Ellyn, 343 III. 489, 175 N.E. 770 (1931), denying equitable relief (quiet title) on the ground that equity will not enforce a forfeiture. For the later proceedings in ejectment, see 374 IIl. 50, 27 N.E. 2d 821 (1940); Barnesville v. Stafford, 161 Ga. 588, 131 S.E. 487 (1926); 4 Thompson on Real Property $\S 2150$ (3d ed., 1940); 2 Pomeroy Eq. Jur. $\$ 459$ (5th ed., 1940);

${ }^{66}$ Sherrill v. Sherrill, 211 Ala. 105, 99 So. 838 (1924); Thornton v. Middleton Educ. Corp., 21 Cal. App. 2d 707, 70 P. 2d 234 (1937); see Cal. Code Civ. Proc. (1950) \& 738; cf. Rusch v. Melosh, 133 N.J. Eq. 502, 33 A. 2d 390 (1943); Bernard v. Bowen, 214 N.C. 121 (1938); Ross v. Sanderson, 63 Okla. 73, 162 Pac. 709, L.R.A. 1917c, 879 (1917); Nadler v. Nadler, 242 Wis. 537, 8 N.W. $2 d 306$ (1943); 1 Tiffany on Real Property $\$ 213$ (3d ed., 1939).

${ }^{67}$ See pp. 226-27 supra.

${ }^{68}$ For a general discussion of this problem see 2 Powell on Real Property $\S \S 289-290$ (1950); Rest., c. 11.

69 Rest., § 171.

${ }^{70}$ Mott v. Danville Seminary, 129 Ill. 403, 21 N.E. 927 (1889). 
ples concerning forfeiture discussed above in connection with quiet title proceedings that states have denied partition to the owner of a right of entry. ${ }^{71}$ Where the prior estate can be terminated by notice or other manifestations short of action, there should be no difference between the two types on other grounds.

\section{CONCLUSION}

The above analysis suggests that we must answer the questions posed in the introduction by a statement that there are some different legal consequences which follow from characterizing the facts as that of a determinable estate and a possibility of reverter rather than characterizing them as an estate on condition and power of termination. Whether these differences are "real" or "substantial" is a judgment as to quality on which we may differ.

We should be able to draw the following conclusions:

(1) The control which the future interest has over the enjoyment of the present estate is enlarged by occurrence of the stipulated event but does not seem to turn on the label attached to the facts with the possible exception of the time from which mesne profits are allowed in favor of the owner of the future interest.

(2) While there have been and are in a few jurisdictions different rules as to alienability of the future interest, the trend of decision and statute is toward identity of treatment. There is no difference as to devolution at death.

(3) As to termination or loss of right there seems to be some distinction as to availability of relief against forfeiture, but this distinction seems to be breaking down.

(4) As to availability of remedies, there seems to be a distinction based on form as to whether, in the condition case, the holder of the power has pursued certain formalities such as entry or other manifestation of intent to terminate before commencement of his action.

Are these distinctions substantial or real? The only distinction which concerns a property interest conventionally regarded as of the essence of property (viz., alienability) is a distinction which is disappearing both by statute and case law. The distinctions concerning the statute of limitations and remedies seem formal and not substantial. If these are all there is to the different labels, the distinctions are not likely long to remain. The dis-

71 Plummer v. Worthington, 321 Ill. 450, 152 N.E. 133 (1926); Storke v. Penn. Mutual Life Ins. Co., 390 Ill. 619, 61 N.E. 2d 552 (1945); Cummings v. Lohr, 246 Ill. 577, 92 N.E. 970 (1910); Hart v. Lake, 273 ㄲl. 60, 92 N.E. 286 (1916). See also Bouvier v. B. \& N.Y. Ry. Co., 67 N.J.L. 281, 51 Atl. 781 (1902). 
tinctions concerning relief from forfeiture and waiver, however, concern an area where there may be an important need to have different interests to reflect with certainty different community needs and institutions. If the community (e.g., in oil and gas leases and conditions of support) needs to have an interest which is quickly and certainly cut off on failure to comply with the agreement, it may be desirable as an aid to interpretation of the parties' intent to have two types of defeasance clauses-one which certainly and without defense cuts off the prior interest and one which is subject to equitable defenses. If, however, as seems to be the trend, the correct solution is to regard neither form as conclusive of intention but to look to each type situation (e.g., oil and gas leases, schoolhouse site gifts, conditions of support) to discover what the parties need and intend and what the community can permit them to do, then it would be well to abandon the differences in form which are not substantial and frankly put the decision whether to grant relief from forfeiture or not on the ground of need and intention.

It would appear that other courts could now well reach the conclusion of the Oklahoma court that there is really no difference between the two types of future interests. ${ }^{72}$

72 See page 222 supra. 